\title{
Intraepithelial Carcinoma of the Cervix Uteri in Women Aged under 35 Years
}

\author{
SYLVIA W. DAVIES, RUTH M. KELLY
}

British Medical fournal, 1971, 4, 525-526

\section{Summary}

The number of cases of intraepithelial carcinoma of the cervix among women of different age groups has been related to the number of cervical smears from women of the same age groups. Among women aged 25 to 34 years the incidence of intraepithelial carcinoma was $0.67 \%$ and among those aged 35 to 44 years it was $0.75 \%$. The overall rate of intraepithelial carcinoma in women under 35 years was $0.55 \%$ compared with an overall rate of $0.59 \%$ in women over 35 years.

If screening of women for cervical cancer is to play any part in preventive medicine it is suggested that the national campaign for the early detection of cervical cancer should be expanded to encourage practitioners to take cervical smears from younger women, particularly from those under 35 years.

\section{Introduction}

It was observed that an unexpectedly high number of positive cervical smears, with subsequent histological confirmation of intraepithelial carcinoma, seemed to come from women under the age of 35 years. In order to confirm this observation a survey was carried out on all the material which had been received in the laboratory from 1965 to 1970 . Positive cervical smears, together with the histological results of surgical treatment from women of different age groups, were expressed as a proportion of the total number of smears from women of the same age groups. The results of the survey are presented and discussed.

\section{Material and Methods}

Material was drawn from the Exeter clinical area, including hospital outpatient departments, maternity clinics, city and county local health authority clinics, health centres, and general practice.

In five years 50,000 cervical smears were examined. The records relating to the smears were reviewed and from each was extracted the age of the woman at the time that the smear was taken. Excluded from the total were data that recorded unsatisfactory smears and others in which the age had not been given. This left a total of 45,525 records for analysis. A repeat negative smear was recorded as a second unit since the age of the woman at the time of the second smear sometimes passed into another age group. On the other hand, all the smears from positive cases, both before and after treatment, were recorded as a single smear for numerical purposes.

A separate analysis of the records of cervical smears that were received during 1966 showed that only 206 of 7,774 were from unmarried, nulliparous women in whom there was no

Area Department of Pathology, Exeter EX2 5AD

SYLVIA W. DAVIES, M.D., M.R.C.PATH., Consultant Pathologist; Senior Lecturer in Pathology, University of Exeter

RUTH M. KELLY, A.I.M.L.T., Department of Cytology history of having taken oral contraceptives. Roughly then, this survey included mainly women at risk.

\section{Results}

\section{POSITIVE SMEARS}

From a total of 45,525 cervical smears the overall rate for positive smears was $0.91 \%$ (Table I). In spite of the recommendation that women aged 35 years and over represent a priority group for screening (enclosure to H.M.(66)76) almost equal numbers of smears were taken from women of age groups 25 to 34,35 to 44 , and 45 to 54 years (Table II). The incidence of positive smears rose in a linear manner through the age groups. In particular, $0.81 \%$ were found among women aged 25 to 34 years compared with $1.0 \%$ among women from 35 to 44 years of age (Table III).

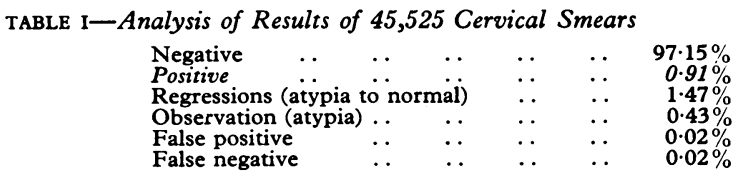

TABLE II-Numerical Analysis of Results of 45,525 Cervical Smears According to Age Groups

\begin{tabular}{|c|c|c|c|c|c|c|c|}
\hline Age in years: & $<20$ & $20-24$ & $25-34$ & $35-44$ & $45-54$ & $55+$ & Total \\
\hline $\begin{array}{l}\text { Negative } \\
\text { Positive } \\
\text { Regressions } \\
\quad \text { (atypia to }\end{array}$ & $\begin{array}{r}397 \\
1\end{array}$ & $\begin{array}{r}3,164 \\
15\end{array}$ & $\begin{array}{r}11,645 \\
97\end{array}$ & $\begin{array}{r}13,352 \\
138\end{array}$ & $\begin{array}{r}10,020 \\
100\end{array}$ & $\begin{array}{r}5,653 \\
64\end{array}$ & $\begin{array}{r}44,231 \\
415\end{array}$ \\
\hline $\begin{array}{c}\text { normal) } \\
\text { Observation }\end{array} \cdots$ & 7 & 83 & 187 & 166 & 146 & 82 & 671 \\
\hline $\begin{array}{l}\text { (atypia) } \\
\text { False positive }\end{array}$ & $\begin{array}{l}6 \\
0\end{array}$ & $\begin{array}{r}38 \\
2\end{array}$ & $\begin{array}{r}51 \\
2\end{array}$ & $\begin{array}{r}53 \\
6\end{array}$ & $\begin{array}{r}31 \\
2\end{array}$ & $\begin{array}{r}17 \\
0\end{array}$ & $\begin{array}{r}196 \\
12\end{array}$ \\
\hline Total & 411 & 3,302 & 11,982 & 13,715 & 10,299 & 5,816 & 45,525 \\
\hline
\end{tabular}

TABLE III-Incidence of Positive Smears per Total Smears from Women of Same Age Group

\begin{tabular}{l|r|r|r|r|r|r}
\hline \multicolumn{1}{c|}{ Age in years: } & $<20$ & $20-24$ & $25-34$ & $35-44$ & $45-54$ & $55+$ \\
\hline Total smears $\begin{array}{l}\text { No. } \\
\%\end{array}$ & 411 & 3,302 & 11,982 & 13,715 & 10,299 & 5,816 \\
Positive smears & 0.24 & 0.45 & 0.81 & 1.00 & 0.97 & 1.10 \\
\hline
\end{tabular}

\section{HISTOLOGICAL CONFIRMATION}

Material for histological confirmation was obtained from 397 patients out of $\mathbf{4 1 5}$ with positive cervical smears (Table IV). In two there were both carcinoma-in-situ of the squamous epithelium and adenocarcinoma of the endocervix. Only 20 patients were lost to follow-up after treatment had been recommended. There were 80 cases of intraepithelial carcinoma, including carcinoma-in-situ and microinvasive carcinoma, in women aged 25 to 34 years.

The incidence of intraepithelial carcinoma of the cervix according to age was obtained when the number of cases in each age group was related to the total number of cervical smears from women of the same age group. The rate was $0.67 \%$ in women aged 25 to 34 years and $0.75 \%$ in those aged 35 to 44 years (Table V). The ratio for intraepithelial carcinoma 
TABLE IV-Histological Results from 415 Positive Smears According to Age Groups

\begin{tabular}{|c|c|c|c|c|c|c|c|}
\hline Age in years: & $<20$ & $20-$ & 25- & $35-$ & $45-$ & $55+$ & Total \\
\hline $\begin{array}{l}\text { Dysplasia } . \\
\text { Carcinoma-in-situ .. } \\
\text { Microinvasive carcinoma } \\
\text { Carcinoma-in-situ plus }\end{array}$ & $\begin{array}{l}1 \\
0 \\
0\end{array}$ & $\begin{array}{l}4 \\
5 \\
2\end{array}$ & $\begin{array}{r}9 \\
75 \\
5\end{array}$ & $\begin{array}{l}6 \\
92 \\
11\end{array}$ & $\begin{array}{r}4 \\
45 \\
12\end{array}$ & $\begin{array}{r}4 \\
14 \\
1\end{array}$ & $\begin{array}{r}28 \\
231 \\
31\end{array}$ \\
\hline microinvasive carcinoma & 0 & 7 & 80 & 103 & 57 & 15 & 262 \\
\hline $\begin{array}{l}\text { Invasive carcinoma } \\
\text { Adenocarcinoma }\end{array}$ & $\begin{array}{l}0 \\
0\end{array}$ & 0 & 3 & 23 & 33 & 40 & 100 \\
\hline $\begin{array}{ll}\text { Adenocarcinoma } & \ldots \\
\text { No histology } & \ldots\end{array}$ & $\begin{array}{l}0 \\
0\end{array}$ & $\begin{array}{l}0 \\
4\end{array}$ & 4 & $\begin{array}{l}2 \\
4\end{array}$ & $\frac{1}{5}$ & 3 & 20 \\
\hline Total & 1 & 15 & 97 & 138 & 100 & 65 & $417^{*}$ \\
\hline
\end{tabular}

*Double pathology in two cases.

TABLE v-Incidence of Histological Changes Related to Age Groups and Total Smears from Women of the Same Age Groups (per cent)

\begin{tabular}{|c|c|c|c|c|c|c|}
\hline Age in years: & $<20$ & $20-$ & 25- & 35- & 45- & $55+$ \\
\hline $\begin{array}{l}\text { Total smears } \quad . \\
\text { Dysplasia } \\
\text { Carcinoma-in-situ } \quad \ldots \\
\text { Microinvasive carcinoma } \\
\text { Carcinoma-in-situ plus } \\
\text { microinvasive }\end{array}$ & $\begin{array}{l}411 \\
0 \cdot 2 ; \\
0.00 \\
0.00\end{array}$ & $\begin{array}{l}3,302 \\
0 \cdot 12 \\
0 \cdot 15 \\
0.06\end{array}$ & $\begin{array}{l}11,982 \\
0.07 \\
0 \cdot 62 \\
0.04\end{array}$ & $\begin{array}{l}13,715 \\
0 \cdot 04 \\
0 \cdot 67 \\
0.08\end{array}$ & $\begin{array}{l}10,299 \\
0 \cdot 04 \\
0 \cdot 43 \\
0 \cdot 11\end{array}$ & $\begin{array}{l}5,816 \\
0 \cdot 07 \\
0 \cdot 24 \\
0 \cdot 01\end{array}$ \\
\hline $\begin{array}{ll}\begin{array}{ll}\text { carcinoma } \\
\text { Invasive carcinoma }\end{array} \\
\text { Adenocarcinoma } & \ldots \\
\text { No histology } \quad . . & \ldots\end{array}$ & $\begin{array}{l}0.00 \\
0.00 \\
0.00 \\
0.00\end{array}$ & $\begin{array}{l}0.21 \\
0.00 \\
0 \cdot 00 \\
0 \cdot 12\end{array}$ & $\begin{array}{r}0.67 \\
0.02 \\
<0.01 \\
0.03\end{array}$ & $\begin{array}{l}0.75 \\
0.17 \\
0.01 \\
0.03\end{array}$ & $\begin{array}{l}0.55 \\
0.32 \\
0.01 \\
0.05\end{array}$ & $\begin{array}{l}0.26 \\
0.69 \\
0.05 \\
0.05\end{array}$ \\
\hline
\end{tabular}

TABLE VI-Distribution of Intraepithelial and Invasive Carcinoma of Cervix in Women under 35 Years

\begin{tabular}{|c|c|c|c|c|}
\hline \multirow{2}{*}{\multicolumn{2}{|c|}{ Age }} & \multicolumn{3}{|c|}{ Number of Cases } \\
\hline & & Carcinoma-in-situ & $\begin{array}{c}\text { Microinvasive } \\
\text { Carcinoma }\end{array}$ & $\begin{array}{c}\text { Invasive } \\
\text { Carcinoma }\end{array}$ \\
\hline $\begin{array}{l}22 \\
23 \\
24 \\
25 \\
26 \\
27 \\
28 \\
29 \\
30 \\
31 \\
32 \\
33 \\
34\end{array}$ & $\begin{array}{l}\ldots \\
\cdots \\
\cdots \\
\cdots \\
\cdots \\
\cdots \\
\cdots \\
\cdots\end{array}$ & $\begin{array}{r}2 \\
2 \\
1 \\
6 \\
5 \\
11 \\
7 \\
11 \\
6 \\
8 \\
4 \\
8 \\
9\end{array}$ & $\begin{array}{l}1 \\
0 \\
1 \\
0 \\
0 \\
0 \\
0 \\
0 \\
2 \\
0 \\
0 \\
3 \\
0\end{array}$ & $\begin{array}{l}0 \\
0 \\
0 \\
0 \\
0 \\
0 \\
0 \\
0 \\
0 \\
0 \\
0 \\
2 \\
1\end{array}$ \\
\hline
\end{tabular}

between age groups 25 to 34 and 35 to 44 years was $1: 1 \cdot 12$. In addition, the overall incidence of intraepithelial carcinoma in women under 35 years was $0.55 \%$ compared with $0.59 \%$ in women aged 35 and over.

In order to show that intraepithelial carcinoma in women under 35 years is not confined to women in their early thirties the distribution of histologically confirmed cases according to age is shown in Table VI.

\section{Discussion}

In this country the screening of women for cancer of the cervix by means of exfoliative cytology is concentrated on women aged 35 and over. That this is so is shown by the continued use of the Department of Health and Social Security form E.C.74.

Various authors have remarked on the fallacy of this policy, and comments such as "amazed" (Lucas, Glover, and Attwood, 1968), "not only mystical but also mythical" (Way, Hennigan, and Wright, 1968), and "irrational" (Jordan, 1969) have been offered.

Similar surveys to ours have been made. In some, age groups have been divided by decades for the purpose of analysis. The values which have been reported for the age-specific incidence of carcinoma-in-situ range from 1.6 to 2.5 per 1,000 for age group 20 to 29 years to 3.0 to 8.4 per 1,000 for age group 30 to 39 years and to 4.4 to 5.9 per 1,000 for age group 40 to 49 years (Nieburgs, Stergus, Stephenson, and Harbin, 1957; Stern, 1959; Johnson, Nickerson, Easterday, Stuart, and Hertig, 1968;
Robertson and Crozier, 1968; Willis and Woods, 1969; Christopherson, Mendez, Ahuja, Lundin, and Parker, 1970).

When the rate for carcinoma-in-situ has been analysed according to the same age groups as ours values range from 4.4 to $5 \cdot 2$ per 1,000 for age group 25 to 34 to 4.7 to 10.3 per 1,000 for age group 35 to 44 and to 4.7 to 10.9 per 1,000 for age group 45 to 54 years (Dunn, 1966; Macgregor, 1967; Fidler, Boyes, and Worth, 1968).

It is generally believed that about one-quarter to one-third of untreated cases of carcinoma-in-situ will progress to invasive carcinoma (Petersen, 1956; Younge, 1965; Sedlis, Cohen, and Sall, 1970). However, up to the present time there is no established means by which the cytologist and the pathologist can predict, in an individual case, whether the intraepithelial lesion would have progressed to invasive carcinoma if conization of the cervix had not been performed; it is also impossible to predict the rate at which the lesion might have progressed.

The five-year survival rate for invasive carcinoma of the cervix, with treatment, varies between $68 \%$ for stage 1 and $7 \%$ for stage 4 (Campbell, 1966). The rate of recurrence of intraepithelial carcinoma after treatment varies between 1 and $13 \%$; the results depend largely on the type of surgical treatment (Cox, 1967). If the purpose of the cervical cytology campaign is to reduce the incidence of invasive carcinoma of the cervix it is important that intraepithelial carcinoma is diagnosed at the earliest opportunity since the likelihood of recurrence is low with adequate treatment.

The enclosure to H.M.(66)76 stated that the scale of expansion for the cytological screening of women for cervical cancer had been based initially on the screening of women aged 35 and over (the priority group) at five-yearly intervals but that the intention was to extend the service as soon as practicable to all women. It is obvious from our figures that cervical smears are, in fact, taken from women of younger age groups. Analysis of the results has shown values for intraepithelial carcinoma of 6.7 per 1,000 for age group 25 to 34 years and $7 \cdot 5$ per 1,000 for age group 35 to 44 years. Moreover, the overall rate for intraepithelial carcinoma in women under 35 years of age is 5.5 per 1,000 compared with an overall rate of 5.9 per 1,000 for women over the age of 35 years.

It would seem that the time has arrived for the cervical cytology service to be extended to include women of younger age groups and that any rescreening programme should also include women under 35 years of age.

We would like to thank Mr. J. Sullivan (secretary, Royal Devon and Exeter Hospitals) and his wife for helping us with the task of going through the records of 50,000 cervical smears. Our gratitude is due to all our medical colleagues of the Exeter clinical area who sent us smears from patients under their care.

\section{References}

Campbell, H. (1966). Fournal of Obstetrics and Gynaecology of the British Commonwealth, 73, 27

Christopherson, W. M., Mendez, W. M., Ahuja, E. M., Lundin, F. E., jun., and Parker, J. E. (1970). Cancer, 26, 29.

Cox, B. S. (1967). Fournal of Obstetrics and Gynaecology of the British Commonwealth, 74, 723

Dunn, J. E. (1966). Proceedings of the Royal Society of Medicine, 59, 1198.

Fidler, H. K., Boyes, D. A., and Worth, A. J. (1968). Fournal of Obstetrics and Gynaecology of the British Commonwealth, 75, 392.

Johnson, L. D., Nickerson, R. J., Easterday, C. L., Stuart, R. S., and Hertig, A. T. (1968). Cancer, 22, 901. Jordan, J. A. (1969). Practitioner, 202, 351. fournal, 4, 578.

Macgregor, J. E. (1967). Lancet, 2, 1296.

Nieburgs, H. E., Stergus, I., Stephenson, E. M., and Harbin, B. L. (1957). Fournal of the American Medical Association, 164, 1546.

Peterson, O. (1956). American fournal of Obstetrics and Gynecology, 72, 1063. Robertson, J. H., and Crozier, E. H. (1968). Irish Medical fournal, 37, 136. Sedlis, A., Cohen, A., and Sall, S. (1970). American fournal of Obstetrics and Gynecology, 107, 1065.

Stern, E. (1959). Cancer, 12, 933.

Way, S., Hennigan, M., and Wright, V. C. (1968). Fournal of Obstetrics and Gynaecology of the British Commonvealth $75,593$.

Willis, J., and Woods, J. (1969). Fournal of the Irish Medical Association, 62, 173 .

Younge, P. (1965). Fournal of Obstetrics and Gynaecology of the British Commonwealth, $72,9$. 